\title{
A STRATEGIC KNOWLEDGE MAP FOR THE RESEARCH AND DEVELOPMENT DEPARTMENT IN A MANUFACTURING COMPANY
}

\author{
Małgorzata ŚLIWA*, Justyna PATALAS-MALISZEWSKA** \\ University of Zielona Góra, Zielona Góra, Poland \\ *e-mail: m.sliwa@iizp.uz.zgora.pl \\ **e-mail: j.patalas@iizp.uz.zgora.pl
}

\begin{abstract}
Knowledge is a corporate resource, being grounds for initiating activities, which is important in a dynamic economy. The difficulties related to obtaining tacit knowledge, related primarily to experience and observation of the knowledge employee (Mendryk, 2011), encourage the companies to use tools supporting knowledge management and location. This article attempts at designing a dedicated, strategic knowledge map for a research and development department in a manufacturing company. Based on the reference works, the detailed characteristics of specific sources of knowledge in a manufacturing company and tools supporting the process of converting the tacit knowledge into explicit one, for example, the knowledge maps, were devised. Then, a strategic knowledge map model was designed for the research and development department (hereinafter abbreviated as SKM - R\&D) in the manufacturing company, comprising the following components: (1) fields of knowledge, (2) internal and external processes in the R\&D department, and (3) sources of knowledge. Then, a practical implementation of the SKM - R\&D model was presented.
\end{abstract}

Keywords: knowledge map, tacit knowledge, explicit knowledge, research and development department, manufacturing company.

\section{$1 \quad$ Introduction}

The dynamics of changes in a production company results nowadays, for example, from employee migration, continuous improvement of the technology and materials used, as well as the need to manage data, information, and knowledge. Knowledge is a corporate resource, being grounds for initiating activities, primarily innovative ones (Drucker, 1964). It is claimed that innovations are the "new knowledge employed in the production process" (Begg, 1997).

Knowledge found in any company takes both an explicit form (formal) and tacit one. Explicit knowledge is recorded in the form of procedures, rules, and other documents available in the company, while tacit knowledge is usually identified with the knowledge held by an employee. The transfer of tacit knowledge is difficult, and usually consists in exchanging tips and comments during informal relations, based on shared cognition and trust (Park, Lee, 2014).

The need to make tacit knowledge formal is perceived primarily in the research and development
(R\&D) departments in production facilities. The difficulties related to obtaining tacit knowledge, related primarily to experience and observation of the knowledge of the employee (Mendryk, 2011), encourage the companies to use tools supporting knowledge management and location. To carry out the process of tacit knowledge transformation (conversion) into the explicit one, first the major sources of the tacit knowledge should be defined. For this purpose, it seems necessary to design a knowledge map for the research and development (R\&D) department, being a tool supporting the presentation of key sources (Gudanowska, 2012).

This article attempts at designing a dedicated, strategic knowledge map for a research and development department in a manufacturing company. Based on the literature research, the detailed characteristics of specific sources of knowledge in a manufacturing company, and tools supporting the process of converting the tacit knowledge into explicit one, for example, the knowledge maps, were devised.

Then, a strategic knowledge map model was designed for the research and development department (hereinafter abbreviated as SKM - R\&D) in the man- 
ufacturing company, comprising the following components: (1) fields of knowledge, (2) internal and external processes in the $R \& D$ department, and (3) sources of knowledge. Then, a practical implementation of the SKM - R\&D model was presented.

\section{Sources of tacit and explicit knowledge}

The basic source of knowledge in an organization is its internal resources collected on the available media in the form of explicit knowledge. Generally speaking, it is considered easy to pass and formalize, and is related to education. The sources of explicit knowledge are reference works, journals, patents, research, and studies (Wrycza, 2010). Tacit knowledge is based on the explicit one (Nonaka, et al., 2000). The former type of knowledge, embedded in the employees' minds, is based on individual behaviors and experience (Wrycza, 2010).

Another approach is naming the source of knowledge based on the access. In this case, we can speak of general knowledge, extensive one, with unlimited access, as well as specific, detailed knowledge of limited accessibility (Karaś, 2012).

Another classification of knowledge in an organization is proposed by Prof. Marszałek-Surówka, based on Frank Blackler's division classifying knowledge based on the place of its embedding (MarszałekSurówka, 2012):

- knowledge in the mind - based on the conceptual abilities and cognitive intelligence (relating to abstract knowledge),

- knowledge in an individual - oriented on action and context (partially explicit), for example, the ability to solve problems, learning by acting,

- knowledge in culture - open to negotiations, social, combining socialization components,

- knowledge in the group - present in employee's behavior, in the routine actions; created by relations between individual roles, procedures and technology; it is believed conditional on the organizational competence,

- encoded knowledge - expressed by symbols, representing explicit knowledge; it takes a form of, for example, designs, handbooks, and electronic documents.
The most rudimentary source of internal knowledge is the skills of individual employees. The external sources of knowledge include the ones inaccessible to the organization. By learning and cooperating with third-party experts acting as consultants, the organization increases the capacities of the knowledge employees and supports them in the problem-solving process. Frequently, it happens that due to limited financial resources or advanced technologies, the $\mathrm{R} \& \mathrm{D}$ department must use external resources of knowledge. However, what counts is collecting it. By such actions, the company becomes more competitive, learns sector-specific technical innovations, minimizes threats, and gets to know the new markets. The environmental dynamics and innovativeness accompanying the research and development lead to rapid aging of the knowledge present solely within the organization. The external sources of knowledge include (Dohn, 2012):

- independent experts,

- scientists,

- research centers,

- universities,

- knowledge brokers,

- consulting companies,

- suppliers,

- customers.

The development of companies brings growing stress on structuring and segregating knowledge based on the assumed keys, using information technologies to support rapid data localizing. A majority of smart organizations $(82.8 \%)$ allocates the duties related to collecting, processing, or using the outsourced information to a specific person (Kordel, et al., 2010). And yet, in the corporate structures, it is believed that the main unit responsible for collecting knowledge is the marketing department (Kordel, et al., 2010). It was found that, about $91 \%$ of the Polish smart companies in the small/medium/large enterprises (SMLE) sector noticed a knowledge gap in their organization. 
Table 1. Methods of exchanging explicit and tacit knowledge in a company (source: own compilation based on Skarka W., 2007, pp.34)

\begin{tabular}{|c|c|}
\hline Tacit knowledge & Explicit knowledge \\
\hline $\begin{array}{l}\text { - internal benchmarketing (among } \\
\text { offices worldwide), } \\
\text { - ensuring participation of people } \\
\text { having different experience in } \\
\text { teams - naming an experienced } \\
\text { supervisor for new project man- } \\
\text { agers, } \\
\text { - open space offices (in selected } \\
\text { units), } \\
\text { - individual student-oriented teach- } \\
\text { ing: mentoring, coaching, } \\
\text { - meetings of branches, } \\
\text { - regular meetings of project teams, } \\
\text { - active learning (a peculiar type of } \\
\text { training consisting in active par- } \\
\text { ticipation of the trainees), }\end{array}$ & $\begin{array}{l}\text { - } \text { creating reports on external contacts, } \\
\text { - knowledge exchange platform - knowledge base (wiki...), } \\
\text { - tools to distribute strategic information (entry), } \\
\text { - sector-specific discussion forums, } \\
\text { - messengers, } \\
\text { - conference calls/video conferences, } \\
\text { - round-ups of the press/newsletters, } \\
\text { - publications of specialist articles on the corporate website, list } \\
\text { - } \text { of recommended publications, } \\
\text { - thematic lectures (on a given sector), } \\
\text { - software to support group work, } \\
\text { - internet/extranet/intranet } \\
\text { - employee's handbook - a collection of documents facilitating adap- } \\
\text { - tation, base of training materials (on the procedures), } \\
\text { - brainstorming, } \\
\text { - concept trees/ process/thought maps, } \\
\text { - information boards/post-its. }\end{array}$ \\
\hline
\end{tabular}

For this reason, it would be ideal to place all information obtained in an easily accessible database, possibly with access sectors allocated to particular users. The most important type of knowledge in smart organizations is learning new technologies (71\%), and the second one is knowledge enabling to learn innovative products in the sector $(45 \%)$ (Kordel, et al., 2010). This means that the knowledge supporting creation of a new product and process improvement, used mainly in the R\&D department, was named.

The ideology behind knowledge location is a smooth flow of information and quick communication between coworkers. K. Dohn (2012, pp.42-50), referring to G. Probst, names a number of resources based on knowledge identification, for example:

- list of experts' data,

- knowledge map,

- knowledge source map,

- knowledge topography,
- information resource map,

- geographical information systems (GIS),

- knowledge matrices.

After the identification of knowledge and generation of new one, various activities should be initiated to support knowledge exchange in the company. The main methods of exchanging explicit and tacit knowledge are presented in Table 1.

Based on the reference works, the following sources of tacit and explicit knowledge in the R\&D department of a manufacturing company were defined to create a SKM - R\&D model:

a) links for a given type of knowledge - in the form of key words (explicit knowledge),

b) books and other paper forms - if they are available in the facility, with the place of access named (explicit knowledge), 
c) source of knowledge in an electronic form - for example, articles, journals, suppliers' websites, folders with memorandums (explicit knowledge),

d) source of knowledge created within the organization, including the reference to the location of memoranda, results of tests, studies, and so on (tacit knowledge),

e) indication of a person dealing with obtaining a given knowledge-related component (tacit knowledge), f) indication of a similar project with a given subject in the form of a link to the documentation (tacit knowledge),

g) possible knowledge use locations among employee groups; this function is useful when awarding database access to particular users (tacit knowledge),

h) comments with the abbreviated grounds (tacit knowledge).

The following qualification of the knowledge in SKM - R\&D model in the category of the source of knowledge (Fig. 1) was proposed.

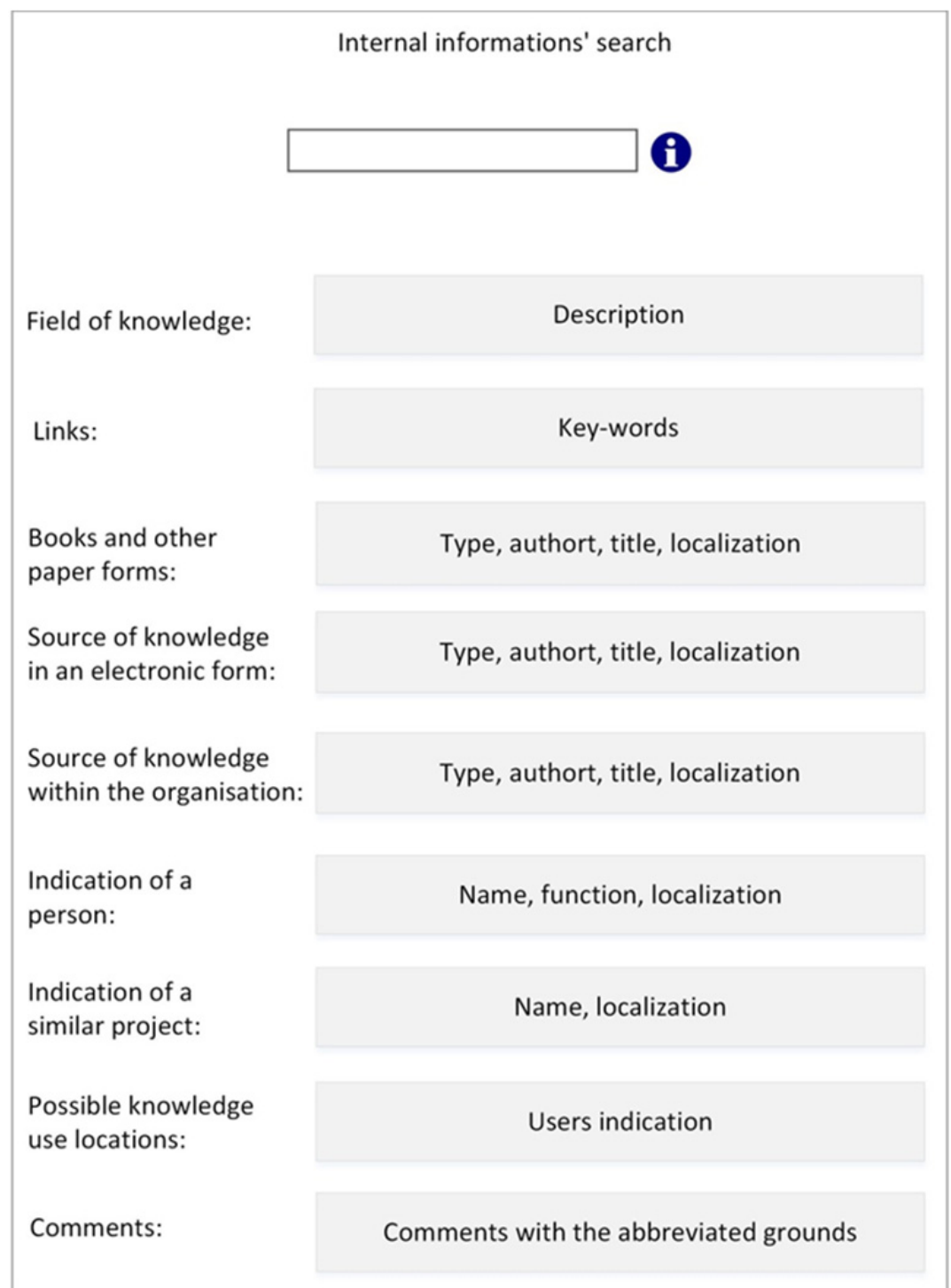

Figure 1. Knowledge classification based on sources of knowledge in the SKM - R\&D model (source: own research)

The following chapter of this article will characterize knowledge maps for companies, and consequently, a project of dedicated strategic knowledge map (SKM - R\&D). 


\section{$3 \quad$ Knowledge maps and their application in a manufacturing company}

The $R \& D$ departments of production facilities notice the need to create internal resources of knowledge and visualize them. Visualization does not only serve to pass information with the sense of sight, but also supports passing experience, opinions, values, and prognoses. It can be used to present one's knowledge with the structure of thoughts and understand the employees' point of view. Knowledge map is presumed to include both explicit and tacit knowledge in the form of objects, with related documents and people (Saad, et al., 2005). Such a tool is to help answer the auxiliary questions, such as "What documents is knowledge collected in? Who uses the knowledge? Who creates it? In what process? How does it affect the organization's objectives? What is required for continued creation of knowledge?" (Gudanowska, 2011). Knowledge maps are aimed at (Kania, 2006): improving identification of knowledge and its sources, helping to interpret and assess knowledge, are a link between processes and sources of knowledge and present the stages of knowledge and skills development.

Moreover, employees are not always aware of the knowledge existence or are not able to find it. Wallis and Wright (2015, pp.2) claim that the very task of correct mapping will be more effective if this is done by a mapping specialist. Knowledge maps, on the other hand, help process the participants who need to carry out knowledge-intensive tasks (Kania, 2006). The following are believed to be the general advantages of knowledge mapping (Tandukar, 2005):

- to find key sources of knowledge creation,

- to encourage reuse and prevent reinvention,

- to find critical information quickly,

- to provide an inventory and evaluation of intellectual and intangible assets,

- to improve decision making and problem solving by providing applicable information,

- to provide insights into corporate knowledge.

The detailed list of process mapping benefits in the company is provided by Kania (2006):
- to detect conflicts between the intended target and the processes carried out,

- to detect interdependencies between process constituents,

- to detect missing processes, gaps, undesirable effects and strengths,

- to juxtapose the processes against known benchmarks (e.g. from other organizations),

- to ensure improved communication with the company's environment,

- to pass mission and tasks to their performers in a clearer way.

It is also necessary to include the benefits of map creation (Eppler, 2004), for example, absolute understanding of the process with simultaneous process improvement, process presentation in the actual condition, with a graphic presentation of all ties, even those not discovered before.

Knowledge map presentation does not have any universal pattern (Gudanowska, 2011). What is more, following Eppler (2004, pp.189-205), five types of knowledge maps used in organizations were distinguished:

1) maps of knowledge sources and experts - here, the example of a map combining the functions of Microsoft Visio software with the knowledge employee base made in Access software is quoted,

2) knowledge competence maps - presented as tables listing the employees and knowledge fields; required to organize training and name experts quickly,

3) knowledge structure map - illustrating with knowledge blocks, functional for example, for product development or project management,

4) knowledge application map - presents the type of knowledge useful for a given process,

5) knowledge development map - created to indicate activities to develop the required competences, for example, process improvement.

The preceding list of map functions shows their potential, highlighting the areas clearly benefiting from mapping. 


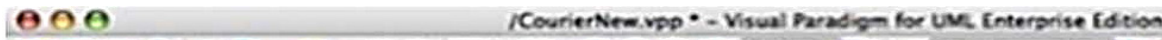

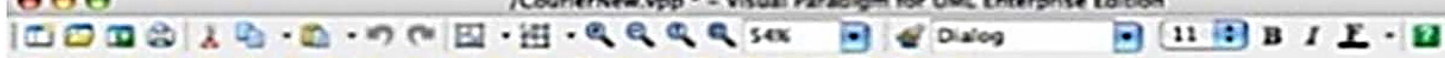

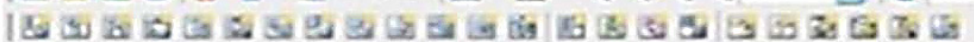

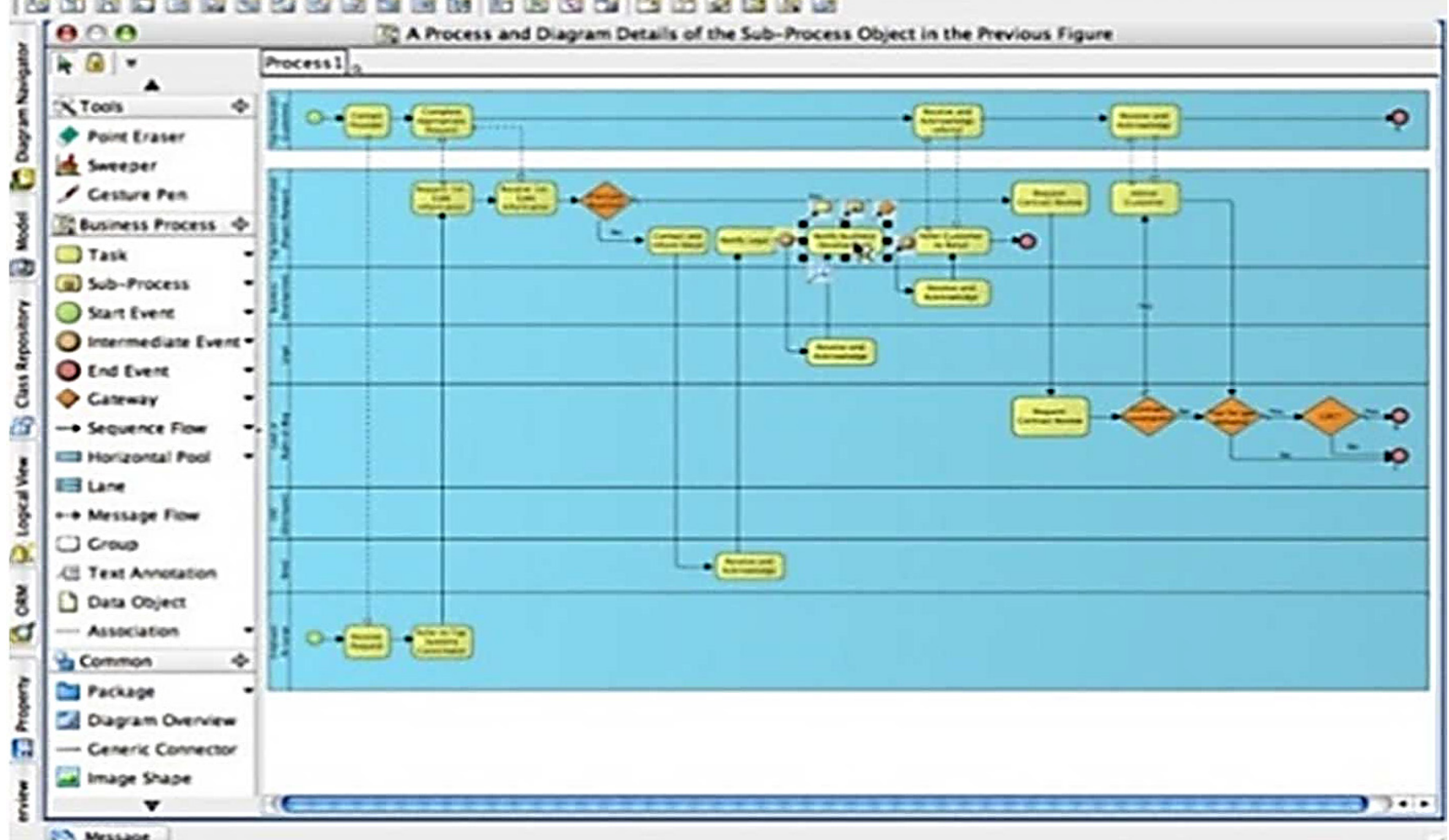

Figure 2. Visual Paradigm interface

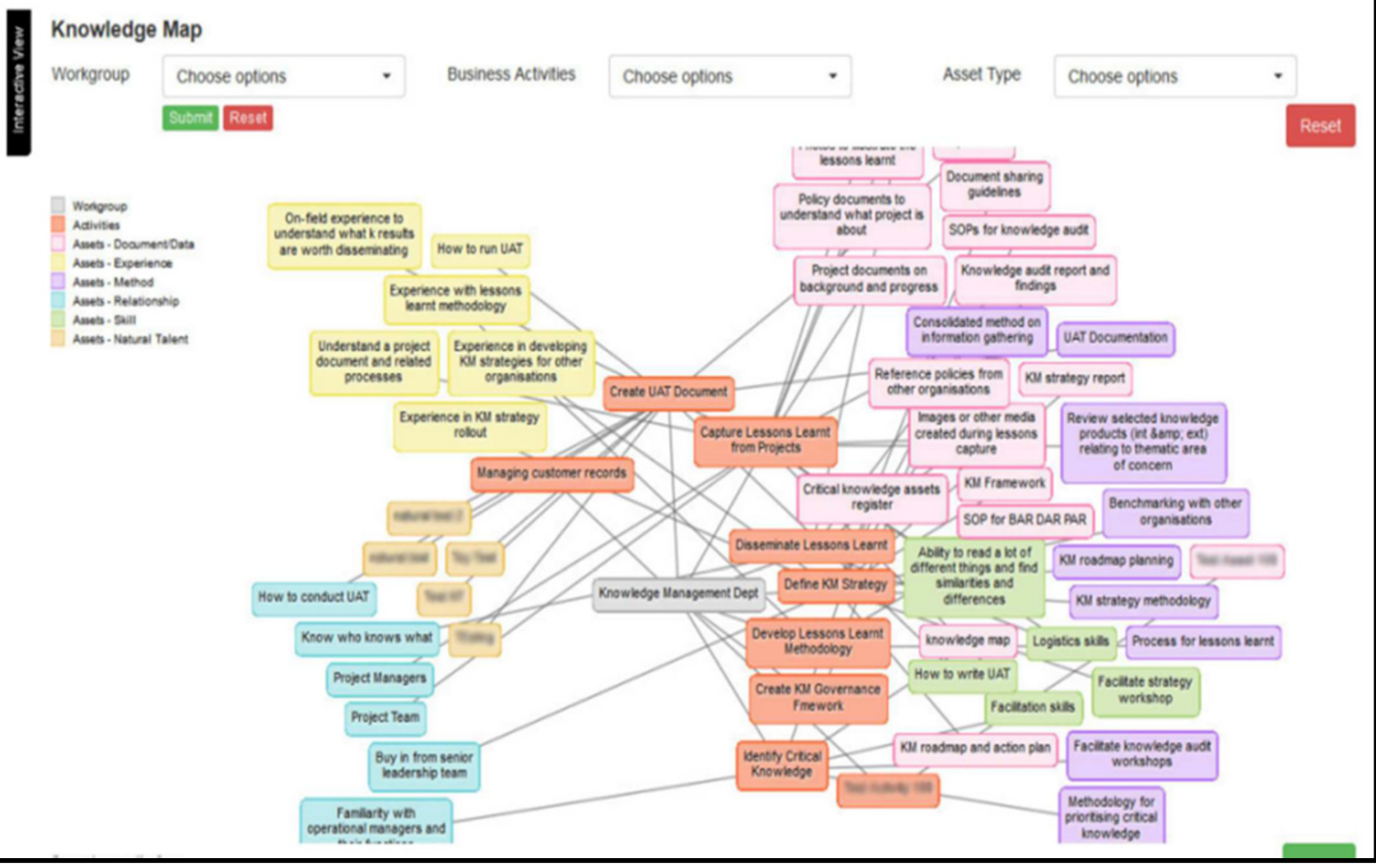

Figure 3. Aithin ${ }^{\mathrm{TM}}-$ Browsing Knowledge Maps interface 
There is a software supporting knowledge map creation in the market, for example, Visual Paradigm in which UML diagrams (Fig. 2) can be created or the Microsoft Visio with a richer interface. Moreover, there are such applications as Aithin (Fig. 3) combining the knowledge base with a search engine, including the key and filters, as well as visualization in a map form.

The use of a strategy map of tacit knowledge in a manufacturing company enables the effective implementation of business strategies, especially for the achievement of the strategic objective: increasing the potential for innovation (Patalas-Maliszewska, Krebs, 2015).

To formulate the SKM - R\&D model, the tasks and interdependencies found when carrying out a new project in the manufacturing company with the $R \& D$ department were defined. Particular departments perform many operations to support project development. Consequently, the basic obligations ascribed to specific units were distinguished:

- R\&D department:

- designing,

- prototype development,

- testing, strength analyses, and so on,

- prototype functionality tests.

- Quality department:

- verification standard requirements,

- quality control of the production process.

- Purchasing department:

- generating RFPs/building a machine park required to ensure continuous production,

- planning warehouse deliveries,

- ensuring quality control tools, for example, checks,

- purchasing materials required for production.

- Controlling department:

- estimating order profitability,

- checking project financing,

- controlling resources/utilities consumed,

- prognoses.

- HR department:
- ensuring white-collar workers for the project,

- ensuring blue-collar workers for the production.

- Sales department:

- eliciting customers,

- managing customer relations,

- price negotiations,

- monitoring.

- Process department:

- planning production,

- planning processes,

- selecting machines,

- selecting tools.

Fig. 4 presents the identified interdependencies between particular units in the manufacturing company during project implementation. They were defined with respect to the R\&D activities and are described by bilateral blue ties. For a representative SME, the following relations were distinguished:

- R\&D department $\rightarrow$ Purchasing department (relationship: orders),

- R\&D department $\rightarrow$ Quality department (relationship: ensuring compliance with the quality requirements),

- R\&D department $\rightarrow$ HR department (relationship: ensuring the required personnel),

- R\&D department $\rightarrow$ Process department (relationship: feasibility verification),

- R\&D department $\rightarrow$ Sales department (relationship: deadlines, requirements, budget limitations)

- R\&D department $\rightarrow$ External specialists (relationship: consultations, obtaining information),

- R\&D department $\rightarrow$ Customer (relationship: feedback).

The two last relationships refer to the knowledge exchange by the internal organization structures with the external community. The preceding description does not detect any direct relationship between the project developed by $R \& D$ and the controlling department. The map diagram also has regular bonds between every department (present in the internal organization space) and the Management Board, marked with dark blue arrows in the diagram. 
Internal organization structures

\section{Purchasing department:}

- generating RFPs/building a machine park required

to ensure continuous production,

- planning warehouse deliveries,

- ensuring quality control tools, e.g. checks,

- purchasing materials required for production.
Controlling department:

- estimating order profitability,

- checking project financing,

- controlling resources/utilities

consumed,

- prognoses.

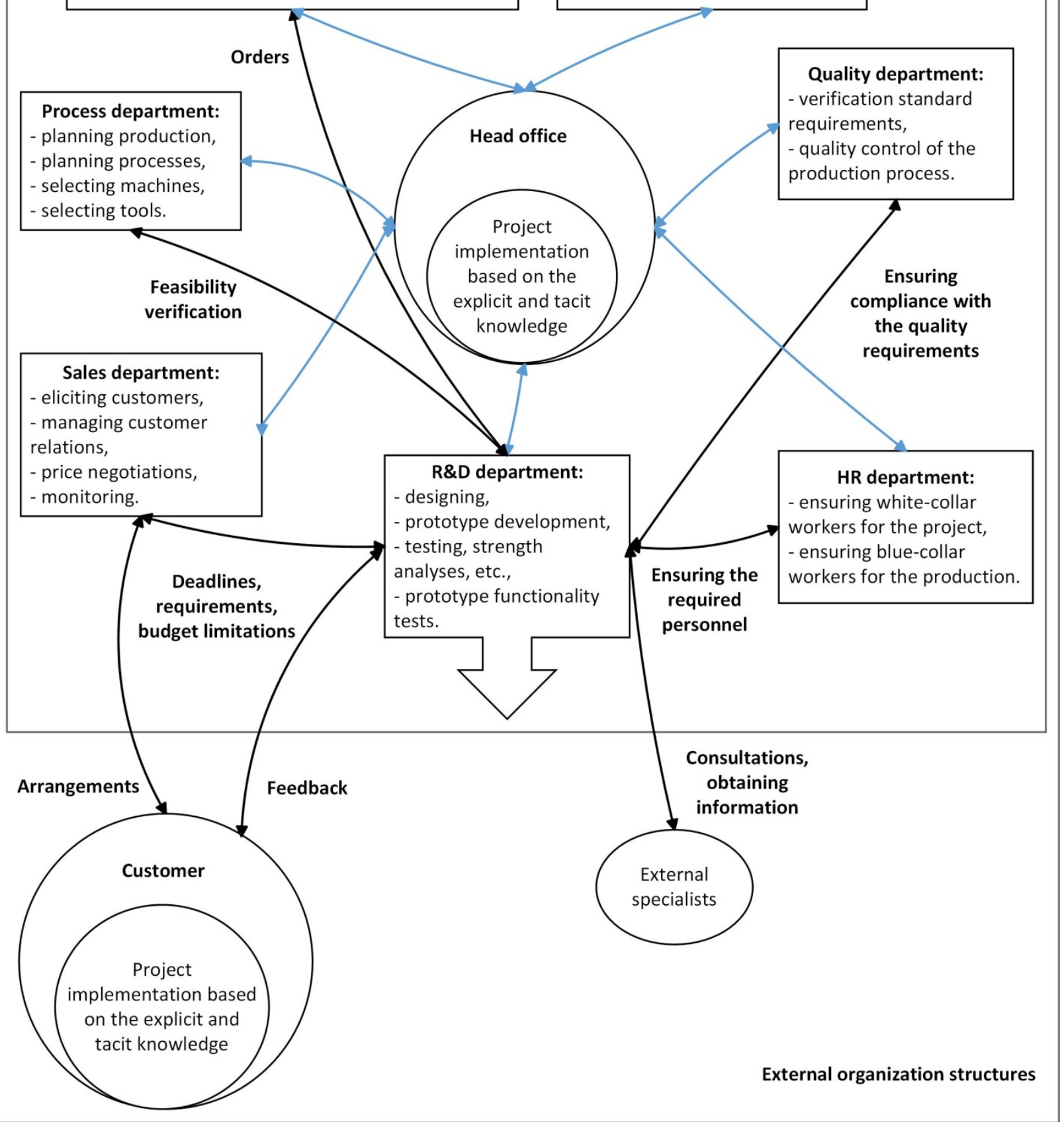

Figure 4. Intra-organization knowledge flow dependence model from the perspective of R\&D department in the context of a new project

(source: own research)

An attempt was made at designing a strategic knowledge map model for the $R \& D$ department (SKM-R\&D) in the manufacturing company, com- prising the following components: (1) fields of knowledge, (2) internal and external processes in the R\&D department, and (3) sources of knowledge. 


\section{Case study - sources of explicit and tacit knowledge in a manufacturing company, using the example of the $R \& D$ department}

The discussed research and development department has operated in the manufacturing company of automotive SME sector, dealing with producing pneumatic components for braking systems and suspension systems in utility vehicles. The $R \& D$ department has received a new project from a key account on a regular basis. The new project resembles a safety valve (test point), used to be produced on a mass scale. The product in question differs pri-
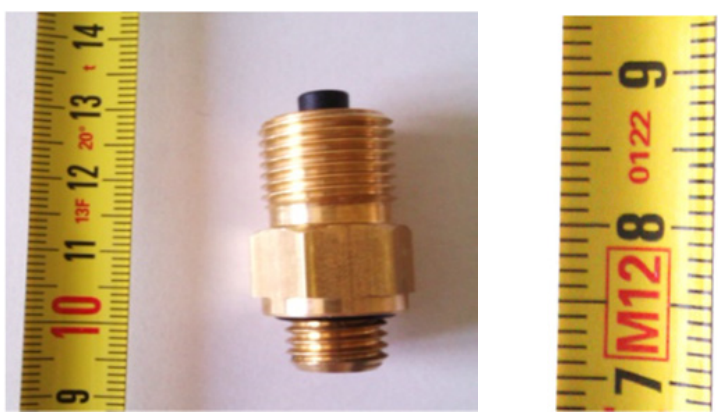

Figure 5. The safety valve being the subject of the new project in the R\&D department in the manufacturing company

There are five employees in the department. Also, the extreme conditions are assumed (belonging to set D0), including the characteristics of the project performed in the R\&D department:

D1: company type: production, automotive sector

D2: company size: SME, current employment: about 70 workers

D3: project assumptions: concurrent engineering, standard-related limitations, functional guidelines from the customer; product alignment with the customer's pneumatic system, reverse engineering

D4: R\&D personnel involved in the task: 3 to 4 people

D5: project budget: from 150,000 to 500,000 PLN

D6: project representative $>28$ years

D7: R\&D manager: 15 years in the team, 17 years of experience in a similar position

D8: number of projects carried out: 6-7 a year marily in terms of requirements concerning the adjustment of threaded components and internal structure to the remaining part of the pneumatic system included in the customer's documents. The project implementation is more difficult this time due to the new functional (quality) requirements. A brass body has a piston, the rubber (NBR) o-ring of which cooperates with the internal wall of the body, ensuring the required tightness to it (Fig. 5). In low operating temperatures, the rubber gets hard and does not display high deformation level, which is why it is difficult to ensure the standard tightness in the circuit.

\section{Component 1 of the SKM-R\&D model, where Ke is explicit knowledge and $\mathrm{Kt}$ - tacit knowledge}

Based on own observations and interview with a knowledge employee from the R\&D department, the following sectors of knowledge, characteristics of the company's working style and the sector were distinguished. They comprise components of the explicit knowledge existing are obtained during project implementation (Ke sector).

$\mathrm{Ke} 1$ : Knowledge of materials and their properties:

Ke11: Strength properties and deformation size for a specific component made from the planned material

Ke12: Resistance to chemicals and other agents the component has contact with during operation

Ke13: Material expansion of the part and its effect on the behavior or the cooperating components of a single product (seizure, tightness, kinematics, and so on)

Ke14: Contact corrosion present for pairs of different materials 
$\mathrm{Ke}$ 2: Geometric and dimensional interdependencies, knowledge obtained on:

$\mathrm{Ke} 21$ : Tolerance and fitting of cooperating components

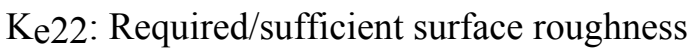

Ke23: Necessary/sufficient conditions of the surface layer of the component (hardness, roughness, and so on)

Ke24: Minimum/maximum thickness of walls in the plastic die stamping, forging, casting, item made by machining

Ke3: Knowledge on the properties of plastic components (components made from polyamide and sealants):

Ke31: Microhardness of materials used for sealants

Ke32: Hardness and strength of plastic components (percentage content of reinforcing agents in the plastic, for example, artificial fiber)

Ke33: Required condition of the plastic component surface (surface roughness, possible flashes at the mould split, traces left by knockouts, their effect on tightness and functionality of components)

Ke4: Knowledge obtained when producing prototypes, from prototype processes:

Ke41: Accuracy of batch production

Ke42: Accuracy of prototype production if the process differs from the target one

Ke43: Prototype strength

Ke44: Usefulness of the prototype made in a given technology for given tests (e.g., strength, tightness)

Ke5: Knowledge obtained when producing design series, for target process:

Ke51: Feasibility

Ke52: Efficiency of the selected process

Ke53: Estimated production duration

Ke54: Required resources: human, machines
Ke6: Knowledge obtained during assembly:

Ke61: The fastest methods of assembling particular components

Ke62: Optimum sequence

Ke63: Assembly speed translating into order performance and number of employees required

Ke64: Cooperation of particular components

Ke65: Assembly feasibility in process-related terms, decision if jobs supporting the assembly process should be created

Ke66: Assessing the opportunities of automating the assembly processes

Ke7: Knowledge obtained during checks:

Ke71: Statistical number of conforming/nonconforming products

Ke72: Meeting customer requirements

Ke73: Selection of the appropriate production technology based on roughness measurements (cutting feed, and speed)

Ke74: Meeting the standard requirements

Ke8: Knowledge obtained during tests:

Ke81: Flow of the preset air volume in the named pressure

Ke82: Component tightness

Ke83: Tightness of threaded connections sealed with o-ring, depending on the torque

Ke84: Relation of wall thickness, set-offs, reliefs and others, analyzed for a finished product subject to tests

Ke85: Knowledge on the contact corrosion resistance for various materials connected together

Kt1: Knowledge on the cooperation of the R\&D department with the customer (feedback)

$\mathrm{Kt2}$ : Knowledge on working in computer-assisted designing software (CAD/CAM)

$\mathrm{K}$ t3: Knowledge of the optimum selection of testing methods

Kt4: Knowledge of the durability/quality of materials used in the design process 
Kt5: Knowledge of the accuracy, quality, strength of materials used in the prototype

Kt6: Knowledge of the prototyping methods (characteristics of a given rapid prototyping technology, filament selection, and so on)

Kt7: Knowledge of cooperation with external units: external specialists/research institutions/consultants

Kt8: Knowledge of usefulness of particular employees for task performance

Kt9: Working-style assessment: for a team and individuals when solving specific problems
Kt10: Knowledge of the optimum sequence of the topics and tasks carried out

Kt11: Knowledge of the actual task performance duration (in relation to a similar project and a similar employee team).

\section{Component 2 of the SKM - R\&D model - internal and external processes in the $R \& D$ department}

Fig. 6 presents the map of process flow in the R\&D department for the development of a new check valve design, composed of the valve body, spring, piston with a seal, and ring.

Table 2. Work stages during a new project development by the R\&D department (source: own research)

\begin{tabular}{|c|c|c|}
\hline Stage no. & Activity description & $\begin{array}{l}\text { Knowledge field obtained } \\
\text { (selected) }\end{array}$ \\
\hline Stage 1 & $\begin{array}{l}\text { The R\&D unit presents a design of a piston cooperating } \\
\text { with an o-ring to its supplier. The unit submits technical } \\
\text { drawings and generates the order. }\end{array}$ & $\begin{array}{l}\text { Knowledge of cooperating with } \\
\text { external specialists }\end{array}$ \\
\hline Stage 2 & $\begin{array}{l}\text { The manufacturer selects the appropriate granulate, designs } \\
\text { the mould, and then supplies the manufactured components } \\
\text { to the R\&D department in the manufacturing company. }\end{array}$ & \\
\hline Stage 3 & The components are assembled by designers. & Knowledge of assembly \\
\hline Stage 4 & $\begin{array}{l}\text { The quality department carries out tightness tests for the } \\
\text { components made. }\end{array}$ & Knowledge of checks and tests \\
\hline Stage 5 & $\begin{array}{l}\text { For a negative test result (NOK), the search for its cause is } \\
\text { initiated. It takes place in consultation with the R\&D de- } \\
\text { partment, which indicates critical properties affecting func- } \\
\text { tionality. The examinations and analyses suggest piston } \\
\text { workmanship inaccuracies, which are quoted as the non- } \\
\text { conformity cause. }\end{array}$ & Knowledge of tests and geometry \\
\hline Stage 6 & $\begin{array}{l}\text { The product is returned to the piston manufacturer as a com- } \\
\text { plaint. The manufacturer makes the product anew. }\end{array}$ & \\
\hline Stage 7 & $\begin{array}{l}\text { The quality department carries out tightness tests for the } \\
\text { components made. }\end{array}$ & Knowledge of checks and tests \\
\hline Stage 8 & $\begin{array}{l}\text { The prototypes made are submitted to the R\&D department } \\
\text { with the specified maximum permissible deviations on the } \\
\text { piston diameter. They are considered conforming, the pro- } \\
\text { ject stage is handed over in the form of documents. }\end{array}$ & $\begin{array}{l}\text { Knowledge of checks and tests, } \\
\text { as well as of material properties }\end{array}$ \\
\hline
\end{tabular}




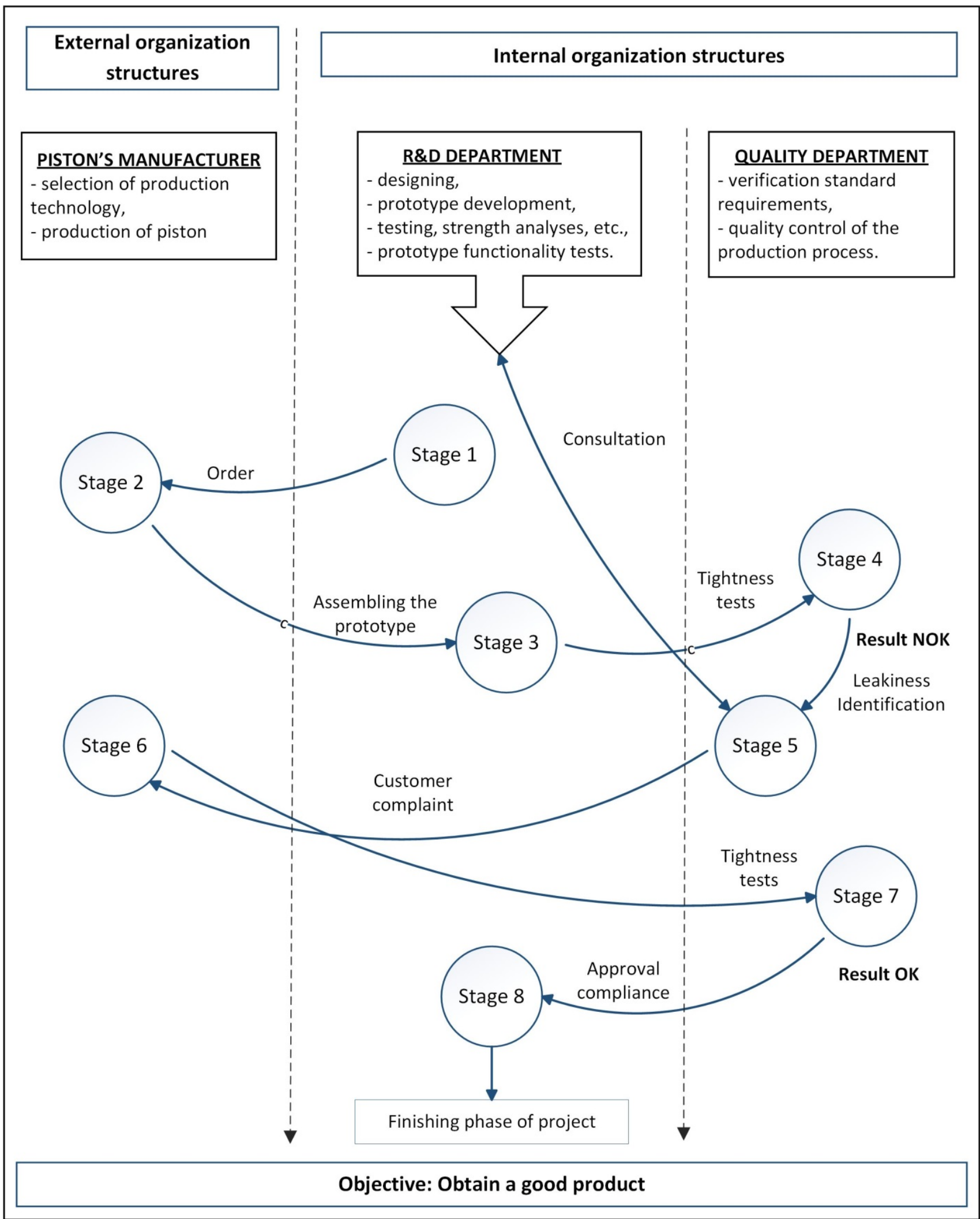

Figure 6. Process flow for problem solving, ensuring product tightness (source: own research) 
The design activity ends, for example, with obtaining new knowledge on the permissible piston diameter deviations, which will not exert adverse influence on the product compliance.

The diagram presents three units participating in obtaining knowledge in the project discussed:

- R\&D department (as the main one) - present in the intra-organization space,

- Quality department - present in the intraorganization space,

- Piston manufacturer (supplier) - present in the extra-organization space.

Works devoted to the problem solving, that is, ensuring the required valve tightness, are listed in Table 2 in the form of eight stages. A short description of a given activity is combined with selected fields of knowledge obtained by the manufacturing company employees.

\section{Component 3 of the SKM - R\&D model - sources of knowledge}

To complement the knowledge base proposed in SKM - R\&D (Fig. 1), the following activities should be carried out:

- Activity 1: Specifying the field of knowledge: "Properties of plastic components".

- Activity 2: Identifying key words: "untightness, flush, piston" in fig. 1 - complemented in the knowledge base for field: "Relations".

- Activity 3: Indicating a person dealing with a given subject: "Jan Kowalski, engineer, room 10 " in fig. 1 - complemented in the knowledge base for field: "erson dealing with a given subject".

- Activity 4: Indicating location of the project where the obtained knowledge was applied: D: \Dokumentacja dział $\backslash$ Klient $\backslash$ Grupa produktów (złącza, zawory...) )projekt_W12_2016 - in Fig. 1 - complemented in the knowledge base for field:
"Projects devoted to similar problems".

- Activity 5: Indicating people or group of employees to offer access to the database whom the obtained knowledge may be useful for: "Process engineers, engineers, quality engineers" in Fig. 1 - complemented in the knowledge base for field:

"Prospective knowledge use locations".

- Activity 6: Indicating justification for the knowledge introduced: "Enclosure from conturography_PROJECT W12_10.01.2016" in Fig. 1 complemented in the knowledge base for field: "Sources of knowledge created inside the organization".

- Activity 7: Indicating reference works in a paper form: PN-EN ISO 4414:2011 ("Pneumatic fluid power. General rules and safety requirements for systems and their components" in Fig. 1 complemented in the knowledge base for field:

"List of paper materials".

- Activity 8: Indicating reference works in an electronic form:

"http://www.o-ringi.Gshop/oringi-materialy,"

"D: $\mid$ Dokumentacja $B+R \mid$ info uszczelnienialNBR" in Fig. 1 - complemented in the knowledge base for field: "Materials available in electronic form".

The R\&D manager should appoint a team representative responsible for introducing the project knowledge unless the company management board creates a separate job.

In Fig. 7, the SKM - R\&D model is created for the field of knowledge: "Properties of plastic components".

When the complete project documentation has been archived and data inserted in the internal database, knowledge mapping and location should be considered completed. Using and finding a similar problem in the future should be faster, with reduced costs of consulting specialists. 


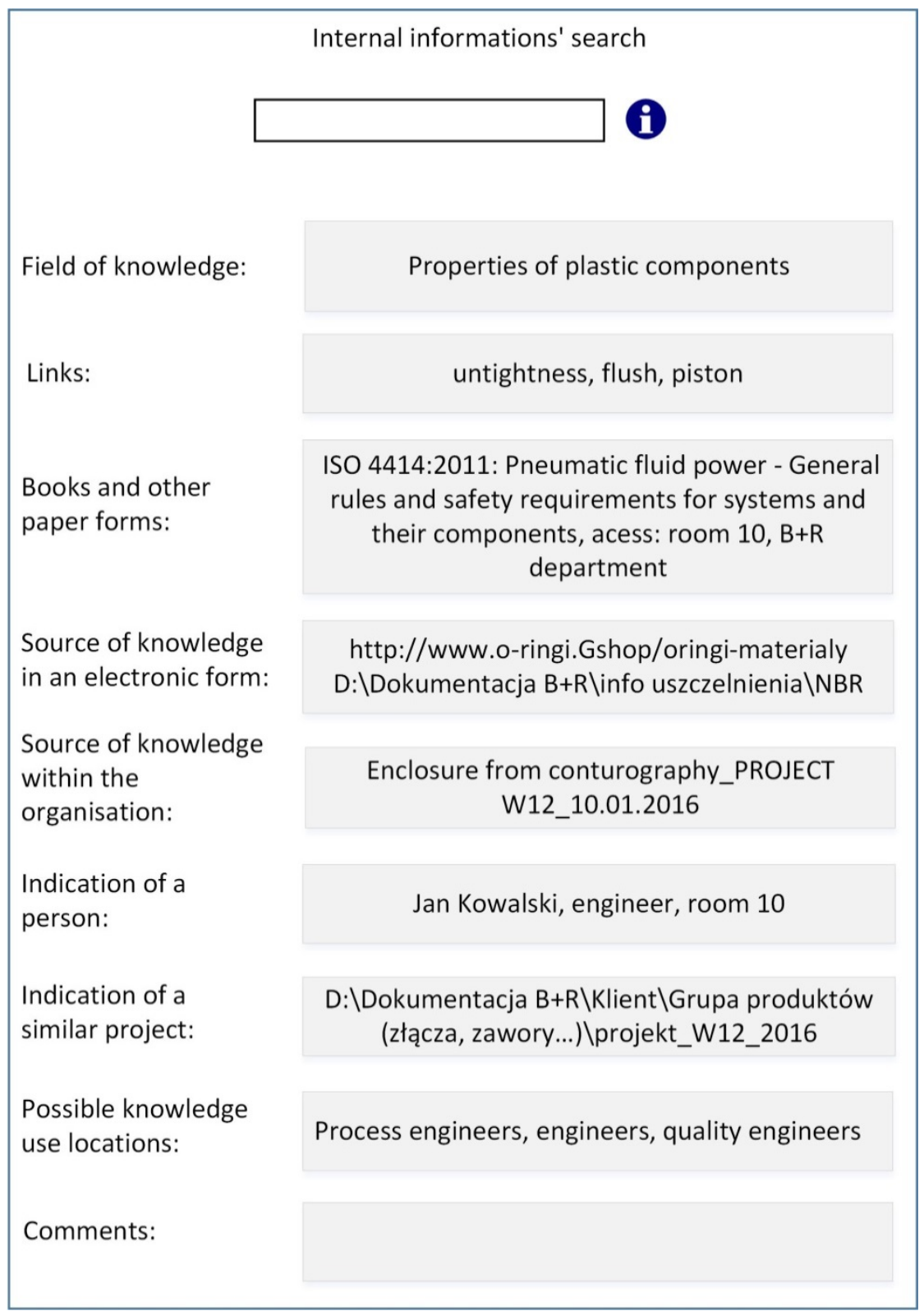

Figure 7. SKM - R\&D model based on the example of the selected field of knowledge (source: own research)

\section{Conclusions}

The suggested method of knowledge mapping and locating should be tested with the R\&D teams composed of white-collar workers allocated to a specific task or project. Using knowledge maps in the company improves identification of knowledge types, its sources, and other interdependencies, which facilitate the processes of searching for appropriate skills and experience, improve the ability to assess and create the intellectual capital of the organization. Thanks to listing knowledge in the department with high information flow, for example, $R \& D$, the company segregates its resources and know-hows, and reduces the costs of consulting the external specialists, training, repeated works on the aspects that have been solved before, as well as ensures faster employees' on-boarding to start works on the new project. This type of knowledge archiving is well-suited for internal audits and external verification of company credibility by the customer. 


\section{References}

[1] Begg, D., Fisher, S., Dornbush, R., 1997. Makroekonomia (Macroeconomic). Warszawa: PWE.

[2] Berchicci, L., 2013. Towards an open R\&D system: Internal R\&D investment, external knowledge acquisition and innovative performance. Research Policy, 42, pp.117-127.

[3] Dohn, K., 2012. Lokalizowanie zasobów wiedzy na potrzeby funkcjonowania przedsiębiorstw przemysłu budowy maszyn (Localization knowledge sources for purposes' functioning enterprises of the mechanical engineering industry). Zeszyty Naukowe Uniwersytetu Szczecińskiego, Ekonomiczne Problemy Ustug. Gospodarka elektroniczna. Wyzwania rozwojowe, 702 (87), pp.42-50.

[4] Drucker, P., 1964. Managing for Results. New York: Harper \& Row.

[5] Eppler, M., 2004. Making Knowledge Visible through Knowledge Maps: Concepts, Elements, Cases. In: C.W. Holsapple, ed., 2004. Handbook on Knowledge Management 1. Heidelberg: Springer Verlag Berlin, pp.189-205.

[6] Gudanowska, A., 2011. Mapy wiedzy jako narzędzie lokalizacji zasobów wiedzy w organizacji (Knowledge maps as tools for location knowledge sources in organization). Problemy Eksploatacji, 82 (3), pp.19-31.

[7] Kania, K., 2006. Procesowe mapy wiedzy i przykład ich zastosowania $\mathrm{w}$ przemyśle odzieżowym (Process knowledge maps and example of using in clothing industry). Systemy Wspomagania Organizacji, [online] Available at: http://www.swo.ae.katowice.pl/_pdf/307.pdf [Accessed 28 May 2016].

[8] Karaś, A., Pyrek, R., 2012. Relacje wynikające z wiedzy i ich rola $\mathrm{w}$ działalności innowacyjnej przedsiębiorstw (Results reports from knowledge relations and their role in innovative activity of enterprises). Zeszyty Naukowe Matopolskiej Wyższej Szkoty Ekonomicznej w Tarnowie, 21 (2), pp.65-76.

[9] Kordel, P., Kornecki, J., Kowalczyk A., et al., 2010. Inteligentne organizacje: zarzadzanie wiedza $i$ kompetencjami pracowników (Smart organizations: knowledge management and em- ployees' competences). Warszawa: Polska Agencja Rozwoju Przedsiębiorczości.

[10] Lambe, P. Knowledge mapping \& analytics using Aithin ${ }^{\mathrm{TM}}$ Software to support knowledge management in your organization. [online] Available at:

http://aithinsoftware.com/doc/Aithin\%20White \%20Paper_A4_v5.pdf [Accessed 5 June 2016].

[11] Marszałek-Surówka D., 2012. Rola wiedzy w kreowaniu innowacji (The role of knowledge in creating innovation). In: B. Mikuła, ed., 2012. Historia i perspektywy nauk o zarzqdzaniu. Kraków: Fundacja Uniwersytetu Ekonomicznego, pp.303-313.

[12] Mendryk, I., 2011. Źródła wiedzy organizacyjnej - wyniki badań polskich przedsiębiorstw (Organizational knowledge sources - results of research in polish enterprises). Zeszyty naukowe. Wspótpraca $w$ tańcuchach dostaw a konkurencyjność przedsiębiorstw i kooperujacych sieci, 32, pp.315-331.

[13] Nonaka, I., Toyama, R., Konno, T., 2000. SECI, Ba and Leadership: a Unified Model of Dynamic Knowledge Creation. Long Range Planning, 33, pp.5-34.

[14] Nowe media i technologie wiedzy w programach studiów ekonomicznych - synergia teorii i praktyki, [online] Available at:

http://www.inzynieriawiedzy.pl/wizualizacjawiedzy/istota [Accessed 5 June 2016].

[15] Park, J.-G., Lee, J., 2014. Knowledge sharing in information systems development projects: Explicating the role of dependence and trust. International Journal of Project Management, 32, pp.153-165.

[16] Patalas-Maliszewska, J., Krebs, I., 2015. A strategy map of tacit knowledge for manufacturing companies. An empirical study. In: Information and software technologies: 21st International Conference, ICIST 2015. Kaunas, Lithuana, 1516 October 2015. Heidelberg, Springer International Publishing Switzerland: Communications in Computer and Information Science, 538, pp.167-174.

[17] Saad, I., Rosenthal-Sabroux, C., Grundstein, M., 2005. Improving the Decision Making Process in the Design Project by Capitalizing on Compa- 
ny's Crucial Knowledge. Group Decision and Negotiation, 14, pp.131-145.

[18] Skarka, W., 2007. Metodologia procesu projektowo-konstrukcyjnego opartego na wiedzy (Methodology of designing-construction process based on the knowledge). Gliwice: Wydawnictwo Politechniki Śląskiej.

[19] Tandukar, D., 2005. Knowledge Mapping, Ezine Articles. [online] Available at:

http://ezinearticles.com/?Knowledge-Mapping \&id=9077 [Accessed 28 May 2016].
[20] Virtual Paradigm. [online] Available at: https://www.visual-paradigm.com [Accessed 5 June 2016].

[21] Wallis, S., Wright, B., 2015. Strategic knowledge mapping: the co-creation of useful knowledge. Developments in business simulation and experiential learning, 42, pp.1-18. [online] Available at: https://journals.tdl.org/absel/index.php/absel/arti cle/view/2899 [Accessed 3 June 2016].

[22] Wrycza, S., 2010. Informatyka ekonomiczna. Podręcznik akademicki (Economical Informatics. Academic Books). Warszawa: PWE. 